\title{
Factors Influencing the Formation of the Educational Choices of Individuals of Different Social Origin: A Review of Recent Sociological Scientific Literature
}

\author{
Georgia Spiliopoulou \& Gerasimos Koustourakis \\ University of Patras \\ Department of Educational Sciences and Early Childhood Education
}

Anna Asimaki

University of Patras, Department of Primary Education

Received 12 May 2018 • Revised 30 June 2018 • Accepted 15 July 2018

\begin{abstract}
The social and cultural origins of students' families contribute to the formation of the students' own culture through the accumulation and engraving of a system of predispositions that influence their educational success. The purpose of this study, which focuses on a review of recent sociological literature, is to explore and highlight the factors that define the choices of individuals from different social backgrounds regarding their educational future. The analysis of the research findings of the relevant scientific papers highlights the impact of socio-economic and cultural factors on the shaping of the educational choices of individuals of different social origin, bringing at the same time to the fore issues of social and educational inequalities. In particular, the social class of origin of young people, which produces its own class dispositions, the family habitus, the volume of cultural, social and economic capital that the student's family possesses, as well as the way in which teachers, who also have their own system of predispositions within the educational institutions where they work, approach young people of different social origin tend to make a significant contribution to the choices that define the educational paths of young people.
\end{abstract}

Keywords: social origin, habitus, cultural capital, social capital, economic capital, educational choices of young people.

\section{Introduction}

The impact of socio-economic and demographic factors and various forms of "capital" on the educational aspirations and choices of members of families of diverse national, social and cultural origins has garnered interest in a large number of scientific papers in the context of a review of Greek and international scientific literature (see: Andres \& Looker, 2001; Archer, 2002; Archer, Halsall, \& Hollingworth, 2007; Baker \& Brown, 2007; Ball, Reay \& David, 2002; Chakhaia, Andguladze, Janelidze \& Pruidze, 2014; David, Ball, Davies \& Reay, 2003; Devine, 2009; Gil-

(C) Authors. Terms and conditions of Creative Commons Attribution 4.0 International (CC BY 4.0) apply. Correspondence: Gerasimos Koustourakis, Department of Educational Sciences and Early Childhood Education, University of Patras, University Campus, 265.04 Rio Patras, GREECE. E-mail: koustourakis@upatras.gr. 
Flores, Padilla-Carmona, \& Suárez-Ortega, 2011; Koustourakis, Asimaki, \& Spiliopoulou, 2016a; Koustourakis, Spiliopoulou, \& Asimaki, 2016b).

In the context of a sociological approach, Bourdieu points out the influence of habitus on the choices of social subjects and the attainment of their goals, arguing that this is "a system of lasting, transposable predispositions that unifies past experiences, functions at every moment as a matrix of perceptions, makes it possible to achieve various tasks" (Bourdieu, 1977: 83). Habitus is thus developed through the accumulation of experiences, and influences the social subjects' decision-making processes and choices (Bourdieu, 1977, 1979).

The purpose of this paper, which focuses on a review of recent sociological scientific literature, is to explore and highlight the factors that define the choices of people from different social backgrounds concerning their educational future.

The content of this work, following the section on the theoretical notes, is shaped by the categorization of the review of the scientific literature into specific sections based on the thematic content of the relevant research studies. In each thematic category, there is a brief presentation of the findings of some representative works that illustrate the findings in these areas. This work closes with the concluding observations.

\section{Theoretical notes}

Cultural capital includes a wide range of habits, skills and attitudes that the individual accumulates from his/her family of origin during his/her primary socialization process (Bourdieu, 1979). In fact, Bourdieu distinguishes three forms of cultural capital $(1986,1994)$ : the engendered (embodied) form - habitus, the objective form (cultural goods which are visible and transmissible to inheritors) and the institutionalized form, in the shape of educational titles (educational qualifications which are legalized through credentials: a form of objectification).

Habitus, the integration of social structures, unconsciously influences the thoughts and practices of individuals within the social world in which they live (Bourdieu, 1990; Smith \& Tinning, 2011: 237). It offers a "window" to the world - "it is the product of history that produces individual and collective practices... It is embodied history, internalized as second nature and so forgotten as history - the active presence of the past of which it is the product" (Bourdieu, 1990: 56; Bourdieu, 2006: 90-91, 94; Kloot, 2009: 473). It also produces practices that are determined by the objective conditions of the existence of the social subjects that carry it, but it can, depending on the circumstances, display a series of "inventions" and be innovative (Asimaki \& Koustourakis, 2014: 126; Corcuff, 2007: 29). In this sense, the concept of habitus is productive and conflicts with the concept of habit (habitude) which is mechanical, reproductive and includes the elements of repeatability and automation (Accardo \& Corcuff, 1986: 69; Asimaki \& Koustourakis, 2014: 126).

The primary habitus formed in early childhood within the family environment is the basis of the constitution of each subsequent habitus. However, the next set of habitus, namely the secondary, are centered on the primary habitus. Thus, each new acquisition fits into the logic of an existing habitus that is restructured into a single but enriched one that is constantly adapting to the necessities and challenges of new, unexpected and changing situations. Namely, habitus is an internalized structure that is in a process of continuous restructuring. In this respect, secondary habitus such as those that are formed in the school, the working environment, the varied social experience and which are introduced into the primary one do not completely eliminate it (Accardo, 1991: 91-92; Bourdieu, 1979: 58; Bourdieu \& Passeron, 1970: 58).

It can therefore be argued that the teachers' habitus is constantly being restructured as it is subject to new life experiences (Accardo, 1991; Bourdieu \& Wacquant, 1992) in relation to the changing position they occupy in the social field (Laberge, 1995). Bourdieu underlines the 
importance of school habitus. He believes that education offers a grid of homotropic predispositions for the individual to integrate, which then function as "unconscious" principles of action, perception, appreciation - assessment or reaction (Accardo, 1991: 86; Bourdieu, 1987: 76).

This particular French Sociologist also talks about the link between habitus and the individual's social class. The class habitus is the common denominator in the different practices of an individual act, but also the 'common matrix' of the practices of all those who have lived in the same or similar conditions of being within the social sphere (Accardo, 1991: 95-99; Bourdieu, 2006: 99). Social classes produce their own habitus and are reproduced by it (but not mechanistically) (Milonas, n.d.: 215; Milonas, 1995: 79).

Economic capital is a source 'directly and immediately convertible into money' (Bourdieu, 1986: 243). It contributes to the enhancement of the educational success of children either through direct investment (e.g., enrollment in prestigious educational institutions) or indirect investment (e.g., financial aid to children during their studies) (Jæger, 2007: 532).

According to the definition given by Bourdieu, social capital is 'the aggregate of the actual or potential resources which are linked to possession of a durable network of more or less institutionalized relationships of mutual acquaintance and recognition' (1986: 248). The volume of social capital that the social subject possesses is a function of the extent of the network of links that he is able to activate, but also of the volume of capital the person acquires from those individuals to which he is linked (Bourdieu, 1994: 92-93).

Social capital is transferred primarily through the family. According to Bourdieu, there is a link between social capital and the 'dominant' social class. Indeed, this capital helps privileged social strata to benefit economically in the labor market thanks to the school titles they hold. However, this cannot be achieved by individuals of non-privileged social strata with similar titles, because the value of the title is inherent in the socio-economic value of the holder (Bourdieu, 1994: 92-93; Patereka, 1986: 52).

The school favors and supports people in the 'dominant' social class, as they already have the cultural resources required by the educational process, while it reinforces the social disadvantages of the non-socially favored. The culture of the bourgeoisie is closer to the culture of the school, and it is difficult for a child of working-class origin to adopt it, as the culture of the school is unfamiliar to the family environment in which the working-class child grew up. This child can only acquire, through arduous effort, the taste, style, spirit and savoir-vivre that are 'natural' elements of the culture of the 'cultivated' social class and which the school calls for and legitimizes. The ability of a child to meet the demands of education is a direct function of the culture or otherwise of the cultural capital transferred to him/her by his/her family (Bourdieu \& Passeron, 1996: 76-78; Milonas, n.d.: 213).

The most socially privileged have the ability to transfer and legitimize the 'dominant' culture, thus maintaining their advantageous position vis-à-vis the non-privileged individuals who do not have the same resources and the same opportunities to acquire the 'legitimate' cultural capital. Educational action within the school transfers the 'dominant' culture and contributes to the reproduction of the structure of power relations within society (Bourdieu \& Passeron, 1990; Azaola, 2012: 83).

\section{The impact of social origin on the choice of studies in higher education}

Recent sociological studies have shown that despite the increasing number of young people gaining access to higher education, the distribution of the student population is unequal, favoring individuals from the privileged social strata (see: Ball, Davies, David \& Reay, 2002; Iannelli, 2007; Kyridis, 2015; Machin \& Vignoles, 2004; Sianou-Kyrgiou, 2006, 2008, 2010; 
Thompson, 2009; Whelan \& Hannan, 1999). It therefore appears that under-representation of young people from less favored social backgrounds in higher education in countries with high social stratification, such as the United Kingdom and the United States, is an ongoing reality. In this respect, increasing access to higher education tends to favor students from already well-off socio-economic and cultural environments (see: Crozier, Reay, Clayton, Colliander, \& Grinstead, 2008; Goldrick-Rab, 2006; Metcalf, 1997; Pugsley, 1998; Reay, 1998; Reay, David, \& Ball, 2001, 2005; Wakeling, 2005; Waters \& Brooks, 2010; Watson, 2013).

Characteristically, the findings of Wakeling's (2005) study conducted in the UK during 1999-2000 showed that students belonging to privileged social classes continued to attend higher education at a higher rate than working-class students. There is also a variation in the students' choice depending on their social background, regarding universities with a higher social standing. It should be noted that in England the greatest social prestige is bestowed on universities with a longer history as compared to newer universities. People from privileged social strata mainly studied in older and more historic universities and they continued their studies at postgraduate level with great ease because they believed they had acquired high educational qualifications during their undergraduate studies. On the other hand, lower-level students chose to study in newer universities with lower social prestige. Therefore, this research shows that the social origin of the students influences the choice of university degree depending on its validity and the prospects for postgraduate studies.

It therefore appears that the system of educational choices made by young people and involving the carrying out of top-level studies is shaped by their class habitus as it in turn is shaped in the contexts of their social origin (Accardo, 1991; Bourdieu, 2006).

4. Forms of family "capital”, social origin and the educational aspirations/expectations and choices of young people and their parents

The results of recent sociological research show that the family habitus, as well as the cultural, economic and social capital that the family has, have a significant impact on shaping the educational choices of young people in the middle and working class. This fact affects in turn the differentiated educational outlets and prospects of the social subjects (Sianou-Kyrgiou, 2010; Sianou-Kyrgiou \& Tsiplakides, 2009, 2011; Spiliopoulou, Koustourakis, \& Asimaki, 2017: 18; Tavares, Tavares, Justino, \& Amaral, 2008; Thompson, 2009; Vryonides, 2003, 2007; Waters \& Brooks, 2010).

In particular, young people from the middle social strata have stronger "stocks" of "family" cultural, economic and social capital and are geared to selecting studies with a high social and academic status, such as medicine and law. The experiences of the parents of young people from the middle social strata who have graduated from higher education seem to reinforce the choices and orientation of their children for university studies. In this case, both young people and their parents aim, through high-quality student choices, to maintain their social status and ensure the reproduction of their social prerogatives. On the other hand, young people of working-class origin whose families have a low volume of social, economic and cultural capital tend to make "pragmatic" choices in search of more "compromising" educational outlets (Lehmann, 2004, 2007a; Pugsley, 1998; Reay, 1998; Reay \& Ball, 1998; Sianou-Kyrgiou, 2010; Sianou-Kyrgiou \& Tsiplakides, 2009, 2011; Vryonides, 2003, 2007; Waters \& Brooks, 2010).

The study by Waters \& Brooks (2010), conducted in 2007-2008 through interviews with students from the UK who came from well-off socio-economic backgrounds and had studied abroad, is characteristic. These individuals were looking for 'adventure and excitement' through study abroad and often sought to postpone the start of their professional career in order to extend their student life. Nevertheless, students from the United Kingdom remained a privileged social group with the experiences they had in their favored socio-economic family environments, but 
also with the "enhanced" financial resources that offered them a safety net for their future aspirations. Moreover, the educational choices made by these individuals resulted in the reproduction of their privileges, which is perceived through their educational path. They studied at prestigious academic institutions abroad, something that was not accidental, but based on their experiences of (private) education and the involvement of their parents in education. In other words, the habitus of the United Kingdom's most socio-culturally privileged students was reflected in the decisions they made as they chose to study at higher academic institutions abroad seeking pleasure and "experience for experience's sake" through an "aesthetic predisposition" (Waters \& Brooks, 2010: 217, 220-222, 224, 226).

Diversity in cultural capital between social classes tends to contribute to differences in the level of participation of young people in higher education, as well as to the possibility of dropping out of studies by some young people (Noble \& Davies, 2009) who considered attending university as a difficult and demanding process that fills them with insecurity and uncertainty (Lehmann, 2004). As a range of international scientific research reveals, non-traditional students, coming from the working-class or those with low family incomes, who study in "good" universities in terms of prestige choose in some cases to drop out of academic attendance. This is because they feel that they do not "fit" in or cannot cope with their fellow students from "privileged" sociocultural environments, thus experiencing a class-cultural "alienation" (Aries \& Seider, 2005; Granfield, 1991; Lehmann, 2007b, 2009a; Quinn, 2004).

Lehmann's study (2007b), conducted through semi-structured interviews between 2001 and 2003 on a sample of 25 students in Southwestern Ontario, Canada, is indicative of the above finding. In particular, it appeared that many students of working-class origin left their studies at university because of class-cultural discontinuities such as the feeling of not belonging to the university field and the inability to interact and communicate effectively with their fellow students who came from privileged social strata. In this case, many young people of working-class origin tended to redefine their educational decisions by choosing diversified outlets. In particular, a number of young people have been geared to post-secondary education options, such as apprenticeship training or community colleges. Yet another section of young people turned to engaging in manual occupations which were akin to their working-class culture of origin (Lehmann, 2007b: 89, 93, 96, 105-106).

However, the findings of other sociological research have shown that many nontraditional higher education students, i.e. working-class students, chose to study at universities with high prestige in order to climb the ladder of social stratification. In this case, these students tended to "degrade" the background of their class of origin by favoring the desire to "transform" and/or improve their position in the social structure (Baker \& Brown, 2007; Lehmann, 2009a, 2009b).

It seems therefore that working-class young people are called upon to reconcile themselves with the conflict that emerges between social mobility, class "loyalty" and class "betrayal" (Lehmann, 2009a: 632), a problem identified as hidden injuries of class (Sennett \& Cobb, 1972, as cited in Lehmann, 2009a: 632) or described as habitus dislocation (Baxter \& Britton, 2001, as cited in Lehmann, 2009a: 632; Lehmann, 2007b, as cited in Lehmann, 2009a: 632).

In this case, it could be argued that the life experiences of people of working-class origin which are unique in their specific contexts but also shared in relation to their structure with other people belonging to the same social class, (re)shape their predispositions which in turn affect the choices that define their educational career (Bourdieu, 2006; Corcuff, 2007: 29; Maton, 2008). 
5. Educational choices of young people according to

their social background and the effects of their school environment

The findings of recent sociological studies reveal that school, through its culture and habitus, which it attempts to cultivate in its students, contributes significantly to shaping the decisions and choices that define the students' educational careers. Moreover, the results of these studies raise questions regarding the existence of class and educational inequalities at the expense of socio-culturally less well-off young people, whose habitus does not go hand in hand with the 'legitimate' school habitus (Mullen, 2009; Oliver \& Kettley, 2010; Pásztor, 2010; Pini, Price, \& McDonald, 2010; Reay, 1998).

Oliver \& Kettley's (2010) study, conducted in 2005 with teachers and students in six institutions in England, is characteristic. This study showed that the teachers' habitus has shaped the attitudes and predispositions of students to a great extent in higher education. More specifically, there have been different practices on the part of teachers which influence their students through counseling and support in order for them to decide whether or not to study at university level. In particular, some teachers welcomed and urged students to apply for elite Universities, acting as "facilitators", while other teachers prevented students from applying, acting as "guardians". In particular, teachers' attitudes towards student attendance at elite universities were dictated by the strength of their conviction to change the status quo that is unequal at the expense of disadvantaged socio-economic groups. These particular teachers sought, through school practice, to encourage students from non-privileged social backgrounds to apply to elite Universities. They attempted to achieve this by bridging the habitus they had acquired from their family with the "cultivated" habitus of the school. The second group of teachers tended to lessen student attendance in elite universities by 'protecting' them from the possibility of feeling that they did not belong in the university field, and the experience of a sense of "alienation" that they had experienced in attending prestigious universities. Thus, teachers' past experiences of higher education have shaped their beliefs and perceptions of what their students should follow. In other words, their predispositions are reflected in a series of values and attitudes that affect their students' choice of higher education (Oliver \& Kettley, 2010: 737, 740-741, 750-751).

According to Bourdieu, the culture of the "sovereign" social class is incorporated into educational institutions. The advantageous position occupied by young people from the "dominant" social class contributes to their educational success, which in turn leads to social reproduction (Harker, 1984, as cited in $\mathrm{Li}$, 2013: 832). In particular, students from family backgrounds whose beliefs and knowledge are consistent with those of "legitimate" school culture and who have the habitus that facilitates the "game" played in school enjoy the appreciation of the teachers in the context of their learning effort. In contrast, the school exacerbates the weaknesses of the non-privileged from a socio-cultural point of view (Bourdieu \& Passeron, 1996: 76; Mills \& Gale, 2002: 110; Milonas, n.d.: 213).

Pini, Price \& McDonald's study (2010), conducted in 2008 through interviews with 13 teachers who taught in rural and remote high schools in Queensland, Australia, is representative of the previous finding. The findings of this research showed that teachers had high educational and professional expectations of the students whose habitus is consistent with that of the school. In particular, teachers expected middle-class students to study at university, following an academic career, in contrast to their expectations of working-class students. Teachers argued that children working on farms had inherited from their family the values of tradition and the experiences they needed to work on a farm. Teachers also saw it as paradoxical that there were some children with limited cultural capital who, however, earned more money from their work than the teachers. It was found therefore that the teachers supported those children who possessed the predispositions, perceptions and the way of thinking and action that the school calls for and legitimizes. Through this support, these children were emotionally empowered, and believed in 
their abilities, which was 'translated' into high academic performance (Pini et al., 2010: 17, 20-21, 27).

\section{Concluding observations}

According to what we have examined above, we come to the following conclusions:

(1) The analysis of the research reveals the impact of socio-economic and cultural factors on shaping the educational choices of people of different social origin. In particular, the young people's social class of origin, which produces its own class dispositions (class habitus), the family habitus, the volume of cultural, social and economic capital that the student's family possesses, as well as the way in which teachers, who carry their own system of predispositions within the educational institutions that the young people attend, approach young people from different social classes, are key factors that influence the decision-making and the choices which identify the young people's educational path.

(2) The educational choices of young people, as shown by most of the sociological research, are shaped by their social class of origin, taking an "incompatible" or "pragmatic" dimension (Bourdieu, 1993). The material living conditions of young people according to their social origin produce experiences of opportunities and non-opportunities, possible and unlikely results, which in turn shape their unconscious feeling about what is possible, unlikely, but also desirable for them. In this way, they learn their "natural" position in the social world and thus form the system of predispositions and choices that define their educational future (Maton, 2008: $58)$.

(3) Young middle-class people tend to choose university studies, making it a part of a 'normal biography' that has historically been shaped within their family environment. The academic choice made by young middle-class people can be identified as an expected process linked to the social class of origin. In this sense, it is a learned educational decision that has been taken in the context of the middle-class family culture (Bourdieu, 1990; Bourdieu \& Passeron, 1996; Du Bois-Reymond, 1998). On the other hand, many young people of a socially-oriented nature tend to adopt a middle-class 'predisposition' and seek to pursue university studies at senior academic institutions of high standing in order to have opportunities for social development. In this case, they tend to 'degrade' the background of their class of origin with their desire to 'transform' their social position so as to rise socially (Baker \& Brown, 2007; Lehmann, 2009a, $2009 \mathrm{~b})$. In many cases, young people in this particular category tend to abandon attendance at university as they feel they do not belong in this particular place in the face of a class-cultural discontinuity or mismatch between school culture and their own class culture. They are consequently led to the search for more "realistic" educational outlets, consistent with their working-class culture of origin (Lehmann, 2007b, 2009a; Quinn, 2004).

(4) According to several sociological studies, school, and more so the university, tends to contribute to the preservation and reproduction of social and educational inequalities as it favors and supports young people from the most privileged socio-cultural environments whose habitus has its own culture (Bourdieu \& Passeron, 1990). Indeed, despite the increasing number of young people accessing higher education, the distribution of the student population is still unevenly shaped and tends to favor students who are already socially, economically and culturally favored. It could therefore be argued that the education system (re)produces the engraving of the "legitimate" culture and thus contributes to the reproduction of power relations between the "dominant" and the "dominated" social groups or social classes (Milonas, n.d.: 229; Milonas, 1995: 83).

Concluding this endeavor, we believe that it would be worthy of scientific interest to carry out a longitudinal investigation and sociological analysis of the scientific work that deals with the choices of young people who identify their educational paths in relation to socio-economic and cultural factors of influence. 
Declaration of interest: Conflict of interest, none.

\section{Acknowledgements}

This work was financially supported by the General Secretariat for Research and Technology (GSRT) and the Hellenic Foundation for Research and Innovation (HFRI) in the context of the action "1 $1^{\text {st }}$ Proclamation of Scholarships from ELIDEK for PhD Candidates" Scholarship Code: 2081.

\section{References}

Accardo, A. (1991). Initiation à la sociologie: l'illusionnisme social: une lecture de Bourdieu. Bordeaux: Le Mascaret.

Accardo, A., \& Corcuff, P. (1986). La Sociologie de Bourdieu. Bordeaux: Le Mascaret.

Andres, L., \& Looker, E. D. (2001). Rurality and capital: Educational expectations and attainments of rural, urban/rural, and metropolitan youth. The Canadian Journal of Higher Education, 31(2), 1-45.

Archer, A. (2002). Change, culture and tradition: British Muslim pupils talk about Muslim girls' post-16 "choices". Race Ethnicity and Education, 5(4), 359-376.

Archer, L., Halsall, A., \& Hollingworth, S. (2007). Class, gender, (hetero)sexuality and schooling: Paradoxes within working-class girls' engagement with education and post-16 aspirations. British Journal of Sociology of Education, 28(2), 165-180.

Aries, E., \& Seider, M. (2005). The interactive relationship between class identity and the college experience: The case of lower income students. Qualitative Sociology, 28(4), 419-443.

Asimaki, A., \& Koustourakis, G. (2014). Habitus: An attempt at a thorough analysis of a controversial concept in Pierre Bourdieu's theory of practice. Social Sciences, 3(4), 121-131.

Azaola, M. C. (2012). Revisiting Bourdieu: Alternative educational systems in the light of the theory of social and cultural reproduction. International Studies in Sociology of Education, 22(2), 81-95.

Baker, S., \& Brown, B. (2007). Images of excellence: constructions of institutional prestige and reflections in the university choice process. British Journal of Sociology of Education, 28(3), 377-391.

Ball, S. J., Davies, J., David, M., \& Reay, D. (2002). "Classification" and "Judgement”: Social class and the "cognitive structures" of choice of Higher Education. British Journal of Sociology of Education, 23(1), 51-72.

Ball, S. J., Reay, D., \& David, M. (2002). "Ethnic Choosing”: Minority ethnic students, social class and higher education choice. Race Ethnicity and Education, 5(4), 333-357.

Bourdieu, P. (1977). Outline of a theory of practice (R. Nice, Trans.). Cambridge: Cambridge University Press.

Bourdieu, P. (1979). La distinction. Critique sociale du jugement. Paris: Les Éditions de Minuit.

Bourdieu, P. (1986). The forms of capital. In: J. G. Richardson (Ed.), Handbook of theory and research for the sociology of education (pp. 241-258). New York: Greenwood Press.

Bourdieu, P. (1987). Choses dites. Paris: Les Éditions de Minuit.

Bourdieu, P. (1990). The logic of practice (R. Nice, Trans.). Stanford, CA: Stanford University Press.

Bourdieu, P. (1993). Sociology in question. London: Sage. 
Bourdieu, P. (1994). Texts of Sociology. Athens: Delfini.

Bourdieu, P. (2006). The sense of practice. Athens: Alexandria.

Bourdieu, P., \& Passeron, J.-C. (1970). La reproduction. Éléments pour une théorie du système d'enseignement. Paris: Les Éditions de Minuit.

Bourdieu, P., \& Passeron, J.-C. (1990). Reproduction in education, society and culture. London: Sage.

Bourdieu, P., \& Passeron, J.-C. (1996). The inheritors: Students and their culture. Athens: Institute of Book A. Kardamitsa.

Bourdieu, P., \& Wacquant, L. (1992). An invitation to reflexive sociology. Chicago: University of Chicago Press.

Chakhaia, L., Andguladze, N., Janelidze, A., \& Pruidze, N. (2014). Identities, cultural capital, educational choices and post-communist transition: an ethnographic study of Georgian youth. Southeast European and Black Sea Studies, 14(2), 301-318.

Corcuff, P. (2007). Les nouvelles sociologies. Paris: Armand Colin.

Crozier, G., Reay, R., Clayton, J., Colliander, L., \& Grinstead, J. (2008). Different strokes for different folks: diverse students in diverse institutions - Experiences of higher education. Research Papers in Education, 23(2), 167-177.

David, M. E., Ball, S. J., Davies, J., \& Reay, D. (2003). Gender issues in parental involvement in student choices of higher education. Gender and Education, 15(1), 21-36.

Devine, D. (2009). Mobilizing capitals? Migrant children's negotiation of their everyday lives in school. British Journal of Sociology of Education, 30(5), 521-535.

Du Bois-Reymond, M. (1998). "I don't want to commit myself yet”: Young people's life concepts. Journal of Youth Studies, 1(1), 63-79.

Gil-Flores, J., Padilla-Carmona, M. T., \& Suárez-Ortega, M. (2011). Influence of gender, educational attainment and family environment on the educational aspirations of secondary school students. Educational Review, 63(3), 345-363.

Goldrick-Rab, S. (2006). Following their every move: An investigation of social-class differences in college pathways. Sociology of Education, 79(1), 61-79.

Granfield, R. (1991). Making it by faking it: Working-class students in an elite academic environment. Journal of Contemporary Ethnography, 20(3), 331-351.

Iannelli, C. (2007). Inequalities in entry to higher education: A comparison over time between Scotland and England and Wales. Higher Education Quarterly, 61(3), 306-333.

Jæger, M. M. (2007). Educational mobility across three generations: The changing impact of parental social class, economic, cultural and social capital. European Societies, 9(4), 527-550.

Kloot, B. (2009). Exploring the value of Bourdieu's framework in the context of institutional change. Studies in Higher Education, 34(4), 469-481.

Koustourakis, G., Asimaki, A., \& Spiliopoulou, G. (2016a). Cultural capital and educational expectations of native and immigrant parents of primary school students: Qualitative study. International Journal of Sociology of Education, 5(3), 166-189.

Koustourakis, G., Spiliopoulou, G., \& Asimaki, A. (2016b). The influence of a family's cultural capital on the formation of the educational and occupational expectations of native and immigrant primary school students. Educational Journal of the University of Patras UNESCO Chair, 3(1), 8-27.

Kyridis, A. (2015). Educational inequality. Thessaloniki: Kyriakidis Bros.

Laberge, S. (1995). Toward an integration of gender into Bourdieu's concept of cultural capital. Sociology of Sport Journal, 12(2), 132-146. 
Lehmann, W. (2004). "For some reason I get a little scared": Structure, agency, and risk in school-work transitions. Journal of Youth Studies, 7(4), 379-396.

Lehmann, W. (2007a). Choosing to labour? School-work transitions and social class. Montreal and Kingston: McGill-Queen's University Press.

Lehmann, W. (2007b). "I just didn't feel like I fit in": The role of habitus in university dropout decisions. Canadian Journal of Higher Education, 37(2), 89-110.

Lehmann, W. (2009a). Becoming middle class: How working-class university students draw and transgress moral class boundaries. Sociology, 43(4), 631-647.

Lehmann, W. (2009b). University as vocational education: working-class students' expectations for university. British Journal of Sociology of Education, 3o(2), 137-149.

Li, H. (2013). Rural students' experiences in a Chinese elite university: capital, habitus and practices. British Journal of Sociology of Education, 34(5-6), 829-847.

Machin, S., \& Vignoles, A. (2004). Educational inequality: The widening socio-economic gap. Fiscal Studies, 25(2), 107-128.

Maton, K. (2008). Habitus. In: M. Grenfell (Ed.), Pierre Bourdieu: Key Concepts (pp. 49-65). Stocksfield: Acumen.

Metcalf, H. (1997). Class and higher education: The participation of young people from lower social classes. London: CIHE.

Mills, C., \& Gale, T. (2002). Schooling and the production of social inequalities: What can and should we be doing? Melbourne Studies in Education, 43(1), 107-128.

Milonas, T. (n.d.). Social reproduction in school. Theory and experience. Athens: Armos.

Milonas, T. (1995). Introductory insights on P. Bourdieu's theory. In: I. Lampiri-Dimaki \& N. Panagiotopoulos (Eds.), Sociology of Paedeia (pp. 76-95). Athens: Kardamitsa-Delfini.

Mullen, A. L. (2009). Elite destinations: pathways to attending an Ivy League University. British Journal of Sociology of Education, 3o(1), 15-27.

Noble, J., \& Davies, P. (2009). Cultural capital as an explanation of variation in participation in higher education. British Journal of Sociology of Education, 30(5), 591-605.

Oliver, C., \& Kettley, N. (2010). Gatekeepers or facilitators: the influence of teacher habitus on student's applications to elite universities. British Journal of Sociology of Education, 31(6), 737-753.

Pásztor, A. (2010). “Go, go on and higher an' higher”. Second-generation Turks' understanding of the role of education and their struggle through the Dutch school system. British Journal of Sociology of Education, 31(1), 59-70.

Patereka, Ch. (1986). Basic concepts of Pierre Bourdieu and Jean-Claude Passeron. Thessaloniki: Kyriakidis Bros.

Pini, B., Price, R., \& McDonald, P. (2010). Teachers and the emotional dimensions of class in resourceaffected rural Australia. British Journal of Sociology of Education, 31(1), 17-30.

Pugsley, L. (1998). Throwing your brains at it: Higher education, markets and choice. International Studies in Sociology of Education, 8(1), 71-90.

Quinn, J. (2004). Understanding working-class "drop-out" from higher education through a sociocultural lens: Cultural narratives and local contexts. International Studies in Sociology of Education, 14(1), 57-74.

Reay, D. (1998). Always knowing and never being sure: Familial and institutional habituses and higher education choice. Journal of Education Policy, 13(4), 519-529.

Reay, D., \& Ball, S. J. (1998). "Making their minds up": Family dynamics of school choice. British Educational Research Journal, 24(4), 431-448. 
Reay, D., David, M., \& Ball, S. (2001). Making a difference? Institutional habituses and higher education choice. Sociological Research Online, 5(4). Retrieved from http://www.socresonline.org.uk/5/4/reay.html

Reay, D., David, M. E., \& Ball, S. (2005). Degrees of choice. Social class, race and gender in higher education. Stoke on Trent, UK: Trentham Books.

Sianou-Kyrgiou, E. (2006). Education and social inequalities - The transition from Secondary to Higher Education (1997 - 2004). Athens: Metaixmio.

Sianou-Kyrgiou, E. (2008). Social class and access to higher education in Greece: supportive preparation lessons and success in national exams. International Studies in Sociology of Education, 18(34), 173-183.

Sianou-Kyrgiou, E. (2010). Stratification in higher education, choice and social inequalities in Greece. Higher Education Quarterly, 64(1), 22-40.

Sianou-Kyrgiou, E., \& Tsiplakides, I. (2009). Choice and social class of medical school students in Greece. British Journal of Sociology of Education, 30(6), 727-740.

Sianou-Kyrgiou, E., \& Tsiplakides, I. (2011). Similar performance, but different choices: social class and higher education choice in Greece. Studies in Higher Education, 36(1), 89-102.

Smith, W., \& Tinning, R. (2011). It's not about logic, it's about logics of practice: a case study of teacher education reform in New Zealand. Asia-Pacific Journal of Teacher Education, 39(3), 235-246.

Spiliopoulou, G., Koustourakis, G., \& Asimaki, A. (2017). Family “capital” and young people's educationaloccupational choices in the context of a review of recent sociological literature. Open Journal for Sociological Studies, 1(1), 15-26.

Tavares, D., Tavares, O., Justino, E., \& Amaral, A. (2008). Students' preferences and needs in Portuguese higher education. European Journal of Education, 43(1), 107-122.

Thompson, R. (2009). Social class and participation in further education: Evidence from the Youth Cohort Study of England and Wales. British Journal of Sociology of Education, 3O(1), 29-42.

Vryonides, M. (2003). Social capital in a historic context of modernization: its effects on Cypriot educational choice-making. Mediterranean Journal of Educational Studies, 8(2), 35-58.

Vryonides, M. (2007). Social and cultural capital in educational research: Issues of operationalisation and measurement. British Educational Research Journal 33(6), 867-885.

Wakeling, P. (2005). La noblesse d'état anglaise? Social class and progression to postgraduate. British Journal of Sociology of Education, 26(4), 505-522.

Waters, J., \& Brooks, R. (2010). Accidental achievers? International higher education, class reproduction and privilege in the experiences of UK students overseas. British Journal of Sociology of Education, 31(2), 217-228.

Watson, J. (2013). Profitable portfolios: Capital that counts in higher education. British Journal of Sociology of Education, 34(3), 412-430.

Whelan, C. T., \& Hannan, D. F. (1999). Class inequalities in educational attainment among the adult population in the Republic of Ireland. The Economic and Social Review, 3O(3), 285-307. 
G. Spiliopoulou, G. Koustourakis \& A. Asimaki - Factors Influencing the Formation of ...

C O A $\mathbf{s}$ 